\title{
Relative Rate and Product Studies of the Reactions of Atomic Chlorine with Tetrafluoroethylene, 1,2-Dichloro-1,2-difluoroethylene, 1,1-Dichloro-2,2-difluoroethylene, and Hexafluoro-1,3-butadiene in the Presence of Oxygen
}

\author{
Thushani N. Herath, Eric C. Clinch, Ivan Orozco, Erin L. Raign, and Paul Marshall* \\ Department of Chemistry, University of North Texas, 1155 Union Circle \#305070, Denton, Texas 76203-5070, United States
}

Supporting Information

\begin{abstract}
Rate coefficients $k_{1}-k_{3}$ have been measured for $\mathrm{Cl}$ atom reactions with $\mathrm{CF}_{2}=\mathrm{CF}_{2}, \mathrm{CFCl}=\mathrm{CFCl}$, and $\mathrm{CCl}_{2}=\mathrm{CF}_{2}$ relative to $k_{4}$ for $\mathrm{CF}_{2}=\mathrm{CF}-\mathrm{CF}=\mathrm{CF}_{2}$ at 293 $\pm 2 \mathrm{~K} . k_{4}$ was remeasured relative to $\mathrm{Cl}+$ ethane. $\mathrm{Cl}$ was generated by $\mathrm{UV}$ photolysis of $\mathrm{Cl}_{2}$, and other species were monitored by FT-IR spectroscopy. The measurements yield $k_{1}=(6.6 \pm 1.0) \times 10^{-11}, k_{2}=(6.5 \pm 1.0) \times 10^{-11}$, and $k_{3}=(7.1 \pm 1.1) \times 10^{-11} \mathrm{~cm}^{3}$ molecule $\mathrm{s}^{-1}$, respectively, and $k_{4}=(8.0 \pm 1.2) \times 10^{-11} \mathrm{~cm}^{3}$ molecule ${ }^{-1} \mathrm{~s}^{-1}$ is proposed. These results are discussed in the context of atmospheric chemistry. Subsequent chemistry in the presence of oxygen leads to oxygenated products that are identified via their IR spectra, and possible mechanisms are discussed. The yield of $\mathrm{CF}_{2} \mathrm{O}$ from $\mathrm{C}_{2} \mathrm{~F}_{4}$ is $93 \pm 7 \%$. Dichlorofluoroacetyl fluoride $\left(\mathrm{CCl}_{2} \mathrm{FCFO}\right)$ was observed as a product from $\mathrm{CFClCFCl}$, and chlorodifluoroacetyl chloride $\left(\mathrm{CClF}_{2} \mathrm{CClO}\right)$ was observed from $\mathrm{CCl}_{2} \mathrm{CF}_{2}$ oxidation. $\mathrm{C}_{4} \mathrm{~F}_{6}$ led to $66 \pm 5 \% \mathrm{CF}_{2} \mathrm{O}$ and $38 \pm 3 \% \mathrm{OCF}_{2} \mathrm{CFC}(\mathrm{F})=\mathrm{O}$. Reaction enthalpies and enthalpy barriers computed via CBS-QB3 theory help rule out some unfavorable mechanistic steps.
\end{abstract}

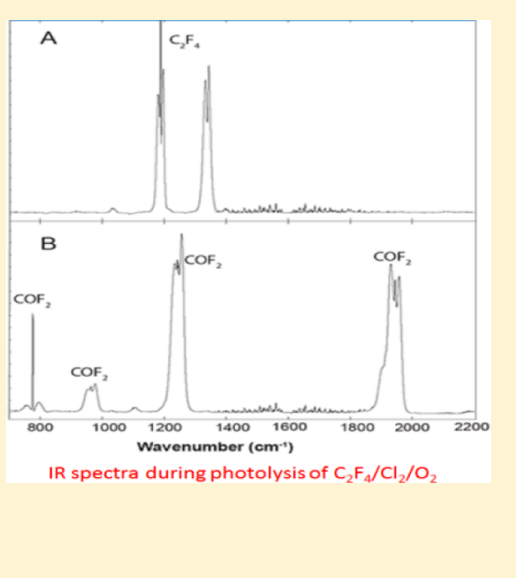

\section{INTRODUCTION}

The Montreal Protocol on Substances that Deplete the Ozone Layer of 1987 addressed the emission of chlorofluorocarbon (CFC) molecules into the atmosphere where, because of their slow reactions with typical tropospheric radicals such as $\mathrm{Cl}$, $\mathrm{OH}$, and $\mathrm{HO}_{2}$, they survive long enough to be transported to the stratospheric ozone layer where they are photolyzed by short-wavelength $\mathrm{UV}$. The resulting $\mathrm{Cl}$ atoms catalyze removal of odd oxygen. ${ }^{1,2}$ Accordingly, CFCs have for many uses been replaced by hydrofluorocarbons (HFCs), which have little ozone depletion potential because of the lack of chlorine. However, their $\mathrm{C}-\mathrm{H}$ bonds react slowly with $\mathrm{OH}$, and the consequential long atmospheric lifetimes combined with strong infrared (IR) absorption in spectral regions not saturated by $\mathrm{CO}_{2}$ absorption lead to very high global warming potentials (GWPs) for HFCs. A context for the work here is exploration of the possibility of employing substitute molecules that contain carbon-carbon $\pi$ bonds that introduce a highly reactive site, so that these molecules may be rapidly scavenged from the atmosphere. Such halo-olefin species have GWPs around 3 orders of magnitude smaller than those of HFCs and have recently been highlighted as practical propellants for aerosol cans and working fluids for refrigeration.

We have made measurements of the rates of the reactions

$$
\begin{aligned}
& \mathrm{C}_{2} \mathrm{~F}_{4}+\mathrm{Cl} \rightarrow \text { products } \\
& (E / Z)-\mathrm{CFCl}=\mathrm{CFCl}+\mathrm{Cl} \rightarrow \text { products }
\end{aligned}
$$

$$
\mathrm{CCl}_{2}=\mathrm{CF}_{2}+\mathrm{Cl} \rightarrow \text { products }
$$

relative to the reference compound perfluorobutadiene, $\mathrm{CF}_{2}=$ $\mathrm{CF}-\mathrm{CF}=\mathrm{CF}_{2}$, whose absolute rate constant is known at room temperature. ${ }^{5}$ These data permit assessment of their atmospheric lifetime with respect to consumption by $\mathrm{Cl}$, which is most relevant to regions where $[\mathrm{Cl}]$ is highest, notably the marine boundary layer $(\mathrm{MBL}){ }^{6}$ The first reaction has not been studied before, and these systems may serve as models that reveal fundamental chemistry that underlies the behavior of larger systems. For all three reactions, our observations of product formation in the presence of oxygen also indicate some of the subsequent fate of these species in the atmosphere and also that for $\mathrm{C}_{4} \mathrm{~F}_{6}$.

\section{METHODOLOGY}

Commercial samples of hexafluoro-1,3-butadiene $\left(\mathrm{CF}_{2}=\mathrm{CF}-\right.$ $\mathrm{CF}=\mathrm{CF}_{2}$, Air Liquide), a mixture of $E$ and $Z$ isomers of $(\mathrm{CFCl}=\mathrm{CFCl})\left(\right.$ Matrix Scientific, 99\%) and $\mathrm{CCl}_{2}=\mathrm{CF}_{2}$ (Synquest, 90\%) were used. We synthesized a few torr of pressure of $\mathrm{C}_{2} \mathrm{~F}_{4}$ by pyrolysis of PTFE under vacuum ${ }^{7}$ [CAUTION: high pressures of $\mathrm{C}_{2} \mathrm{~F}_{4}$ can polymerize explosively]. These reagents, and chlorine (Matheson, $99.9 \%$ ), were purified by repeated freeze-pump-thaw cycles

\footnotetext{
Received: May 26, 2016

Revised: August 30, 2016

Published: August 31, 2016
} 
with liquid nitrogen. The general principles of relative rate measurements are well-established. ${ }^{8}$ In brief, for the present application, molecular chlorine was photolyzed by steady illumination from a mercury lamp in the presence of the reactant olefin and a reference compound. The reference was a molecule whose absolute rate constant for reaction with atomic $\mathrm{Cl}$ was already known. Consumption of the reactant and reference was monitored by infrared spectroscopy, and the relative loss rate was determined, which yielded the ratio of the rate constants for reaction with $\mathrm{Cl}$.

We have assembled a new apparatus where chemistry occurs at room temperature within a Pyrex multipass cell with a $2.4 \mathrm{~m}$ path length (IR Analysis 2.4-PA). The volume is $100 \mathrm{~cm}^{3}$. Prior to each experiment, the cell was evacuated to about $50 \mathrm{mbar}$ and filled with a manometrically prepared mixture of typically around $0.1 \mathrm{mbar}$ of reference compound, around $0.1 \mathrm{mbar}$ of reactant, 0.2-1 mbar of $\mathrm{Cl}_{2}$, and $930 \mathrm{mbar}$ of $\mathrm{Ar}$ (Air Liquide, 99.9995\%). For each reactant, we verified that photolysis in the absence of $\mathrm{Cl}_{2}$ and storage in the dark with $\mathrm{Cl}_{2}$ did not cause any reaction. The cell was mounted inside of a Fourier Transform IR spectrometer (Nicolet iS50) with a mercury cadmium telluride detector cooled with liquid nitrogen, and the UV source was a Pen-Ray 11SC-2.12 lamp with a quartz envelope, supported $2.5 \mathrm{~cm}$ from one side of the infrared cell. This lamp has strong emission in the regions of 184, 254, and $365 \mathrm{~nm}$; the Pyrex walls of the cell are expected to block the first two regions. On the basis of the manufacturer's specifications, the UV intensity at the center of the cell at $365 \mathrm{~nm}$ is about $30 \mathrm{~mW} \mathrm{~cm}{ }^{-2}$. During photolysis, typically 10 spectra were recorded at a rate of $1 / \mathrm{min}$, each with 82 co-added scans at $2 \mathrm{~cm}^{-1}$ resolution. Distinctive peaks in the infrared spectra of the reactant and reference were selected, and the integrated absorbance over the band was evaluated. The concentrations employed correspond to absorbances (base 10) below 1.0 so that Beer-Lambert behavior is expected and the absorbance is proportional to concentration. This was verified in the case of $\mathrm{C}_{4} \mathrm{~F}_{6}$, whose absorbance was checked as a function of the partial pressure of $\mathrm{C}_{4} \mathrm{~F}_{6}$.

With the important assumption that the dominant loss mechanism for both the reactant and the reference is reaction with atomic chlorine, the following reaction scheme can be analyzed:

$$
\begin{array}{ll}
\mathrm{Cl}_{2}+h \nu \rightarrow 2 \mathrm{Cl} & \\
\mathrm{Cl}+\text { reactant } \rightarrow \text { products } & \text { rate constant } k_{\mathrm{R}} \\
\mathrm{Cl}+\text { reference } \rightarrow \text { products } & \text { rate constant } k_{\text {ref }} \\
\mathrm{Cl} \rightarrow \text { loss } &
\end{array}
$$

The products of steps 5 and 6 are radicals that may in turn react with $\mathrm{Cl}_{2}$ to regenerate $\mathrm{Cl}$ atoms. In preliminary tests with ethane $/ \mathrm{Cl}_{2}$ mixtures, an essentially exponential decay of $\left[\mathrm{C}_{2} \mathrm{H}_{6}\right]$ was observed, whose decay constant corresponded to a steadystate concentration $[\mathrm{Cl}]$ on the order of $10^{7}$ atom $\mathrm{cm}^{-3}$. Ethyl radicals formed from $\mathrm{Cl}+\mathrm{C}_{2} \mathrm{H}_{6}$ likely regenerate $\mathrm{Cl}$ atoms via $\mathrm{C}_{2} \mathrm{H}_{5}+\mathrm{Cl}_{2}$. This means that because [Cl] is approximately constant step 7 is seen to balance step 4 . Given that homogeneous $\mathrm{Cl}+\mathrm{Cl}$ recombination is very slow, we conclude that wall losses of $\mathrm{Cl}$ offset its formation via photolysis. We imagine that the inner surface of the cell and the gold mirrors catalytically recombine the $\mathrm{Cl}$ atoms. This is significant because otherwise the overall radical concentrations and reaction rates would increase without limit under steady UV illumination.
With a diffusion coefficient for $\mathrm{Cl}$ of $0.19 \mathrm{~cm}^{2} \mathrm{~s}^{-1}$ at $1 \mathrm{~atm}^{9}$ and treating the cell as a cylinder $11.5 \mathrm{~cm}$ long with a diameter of $3.3 \mathrm{~cm}$, we estimate ${ }^{10,11}$ an effective first-order rate constant of $2.4 \mathrm{~s}^{-1}$ for diffusion loss of $\mathrm{Cl}$ from the long-time solution to the diffusion equation. Because this value is 4 orders of magnitude higher than the observed loss rate (which also includes any reaction of $\mathrm{Cl}$ with impurities such as hydrocarbons in the bath gas), we deduce that the probability of $\mathrm{Cl}$ sticking in an individual collision with the walls is extremely low. We also note that a bulk diffusion time scale of seconds ensures homogeneity in the mixture during the kinetic experiments, which take place on a time scale of minutes.

The rate of step 5 is $k_{\mathrm{R}}[\mathrm{Cl}][$ reactant] so that we may write

$$
-\mathrm{d} \ln [\text { reactant }] / \mathrm{d} t=k_{\mathrm{R}}[\mathrm{Cl}]
$$

Similarly for step 6

$$
-\mathrm{d} \ln [\text { reference }] / \mathrm{d} t=k_{\text {ref }}[\mathrm{Cl}]
$$

Integration of the ratio of expressions 8 and 9 yields the standard result ${ }^{8}$ (where the subscript 0 refers to the initial value and $t$ to a later time)

$$
\ln \left\{\frac{[\text { reactant }]_{0}}{[\text { reactant }]_{t}}\right\}=\frac{k_{\mathrm{R}}}{k_{\text {ref }}} \ln \left\{\frac{[\text { reference }]_{0}}{[\text { reference }]_{t}}\right\}
$$

which is true even if a steady-state $[\mathrm{Cl}]$ is not established or if pseudo-first-order conditions do not hold. In fact, they do here. The ratios of concentrations were determined from the ratios of absorbances. We employed $\mathrm{C}_{4} \mathrm{~F}_{6}$ as the reference compound, for which Wallington and Hurley ${ }^{5}$ have determined, in two runs relative to $\mathrm{Cl}+$ acetylene and ethylene, $k_{\text {ref }}=(6.86 \pm 0.57) \times$ $10^{-11}$ and $(7.70 \pm 0.55) \times 10^{-11} \mathrm{~cm}^{3}$ molecule $^{-1} \mathrm{~s}^{-1}$, respectively. We redetermined $k_{\text {ref }}$ with two runs relative to $\mathrm{Cl}+$ ethane (for which the rate constant is $5.7 \times 10^{-11} \mathrm{~cm}^{3}$ molecule $\left.\mathrm{e}^{-1} \mathrm{~s}^{-1}\right)^{12}$ and obtained ratios of $1.473 \pm 0.018$ and $1.429 \pm 0.032$, which yield $k_{\text {ref }}=(8.40 \pm 0.29)$ and $(8.15 \pm$ $0.41) \times 10^{-11} \mathrm{~cm}^{3}$ molecule ${ }^{-1} \mathrm{~s}^{-1}$. Combination of these four determinations of $k_{\text {ref }}$ yields a weighted mean value (as outlined by Bevington ${ }^{13}$ ) of $8.0 \times 10^{-11} \mathrm{~cm}^{3}$ molecule ${ }^{-1} \mathrm{~s}^{-1}$. Twice the standard deviation of the mean is $0.4 \times 10^{-11} \mathrm{~cm}^{3}$ molecule ${ }^{-1}$ $\mathrm{s}^{-1}$. However, given that the spread between the individual determinations might indicate that systematic errors are present, we prefer a more conservative confidence interval of $\pm 1.2 \times 10^{-11} \mathrm{~cm}^{3}$ molecule $\mathrm{m}^{-1} \mathrm{~s}^{-1}$ for $k_{\text {ref }}$ because this range encompasses all of the measurements.

\section{RESULTS AND DISCUSSION}

Figure 1 shows example plots of $\ln \left\{[\text { reactant }]_{0} /[\text { reactant }]_{t}\right\}$ vs $\ln \left\{[\text { reference }]_{0} /[\text { reference }]_{t}\right\}$, whose slope is $k_{\mathrm{R}} / k_{\text {ref }}$ for the three systems $\mathrm{R}=\mathrm{C}_{2} \mathrm{~F}_{4},(E / Z)-\mathrm{CFCl}=\mathrm{CFCl}$, and $\mathrm{CCl}_{2}=$ $\mathrm{CF}_{2}$. Table 1 lists the experimental conditions for determinations of $k_{\mathrm{R}}$ via eq 10, including the initial concentrations of the reactant and reference, the spectral regions used to assess concentration, and the observed slope of a plot like Figure 1 together with its statistical uncertainty. Table 2 summarizes absolute values of $k_{\mathrm{R}}$ obtained by multiplying $k_{\mathrm{R}} / k_{\text {ref }}$ by the value of $k_{\text {ref }}$ derived above. Each experiment was repeated, and the final result for each reactant was obtained as a weighted mean of the two measurements. The uncertainty quoted here is $2 \sigma$ in the $k_{\mathrm{R}} / k_{\text {ref }}$ ratio combined in quadrature with $3 \%$ for possible propagated systematic errors in concentration and temperature and the error limit for the reference compound ${ }^{5}$ proposed above of $15 \%$. This latter term is dominant so that 

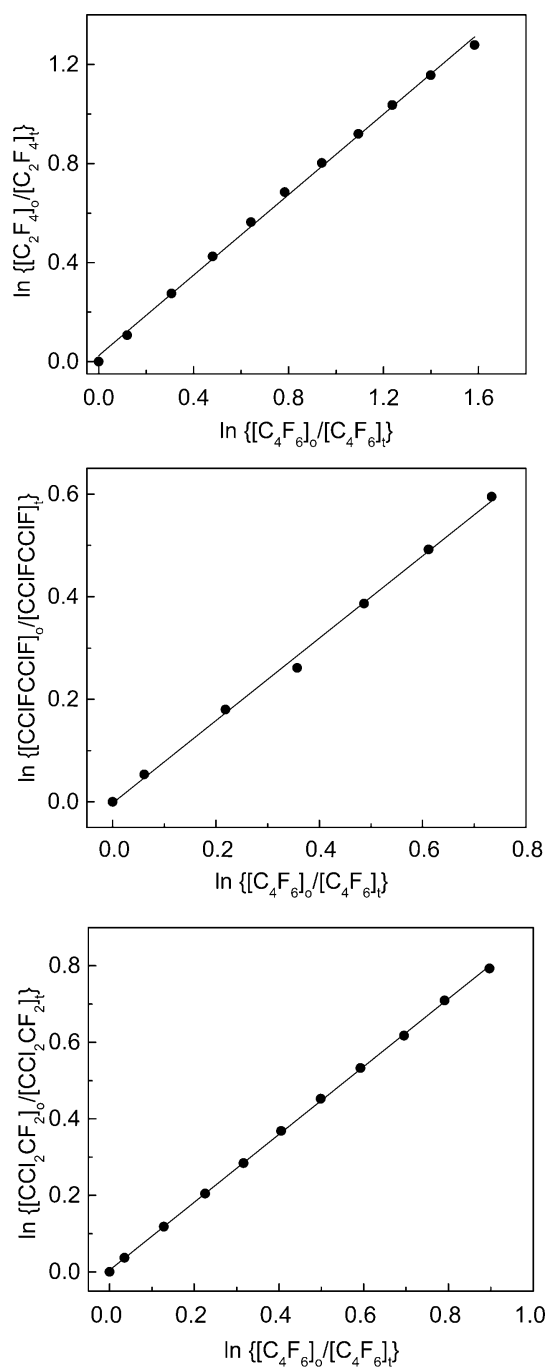

Figure 1. Concentration ratios of reactants vs the reference compound $\mathrm{C}_{4} \mathrm{~F}_{6}$, from top to bottom for the reactions $\mathrm{Cl}+\mathrm{C}_{2} \mathrm{~F}_{4}, \mathrm{Cl}+(E / Z)$ $\mathrm{CFClCFCl}$, and $\mathrm{Cl}+\mathrm{CCl}_{2} \mathrm{CF}_{2}$.

the effective uncertainty in all of the rate constants is $15 \%$. We now discuss each reactant individually.

3.1. Rate Constant and Oxidation Products of $\mathrm{C}_{2} \mathrm{~F}_{4}$. The rate constant for reaction 1 has not been determined previously, but our result of $(6.6 \pm 1.0) \times 10^{-11} \mathrm{~cm}^{3}$ molecule $^{-1} \mathrm{~s}^{-1}$ is comparable to those known for other halogenated alkenes, including $\mathrm{C}_{4} \mathrm{~F}_{6}{ }^{5}$, which are typically around $(5-10) \times 10^{-11} \mathrm{~cm}^{3}$ molecule $\mathrm{c}^{-1} \mathrm{~s}^{-1}$. For a tropospheric daily average $[\mathrm{Cl}]$ of $3 \times 10^{4}$ molecules $\mathrm{cm}^{-3},{ }^{14}$ the lifetime of $\mathrm{C}_{2} \mathrm{~F}_{4}$ with respect to reaction with $\mathrm{Cl}$ is about 6 days. Because hydroxyl is 6 times less reactive toward $\mathrm{C}_{2} \mathrm{~F}_{4}{ }^{15}$ but about 30
Table 2. Summary of the Absolute Rate Constants for Fluorocarbon Reactions with $\mathrm{Cl}$ Atoms at Room Temperature

$\begin{array}{lc}\text { fluorocarbon } & k \pm 2 \sigma / 10^{-11} \mathrm{~cm}^{3} \text { molecule }{ }^{-1} \mathrm{~s}^{-1} \\ \mathrm{CF}_{2}=\mathrm{CF}_{2} & 6.51 \pm 0.18 \\ & 6.66 \pm 0.14 \\ & \mathbf{6 . 5 6} \pm \mathbf{0 . 9 8 ^ { a }} \\ \mathrm{CFCl}=\mathrm{CFCl} & 6.60 \pm 0.31 \\ & 6.43 \pm 0.29 \\ & \mathbf{6 . 5 1} \pm \mathbf{0 . 9 8} \\ \mathrm{CCl}_{2}=\mathrm{CF}_{2} & 7.33 \pm 0.16 \\ & 7.09 \pm 0.07 \\ & \mathbf{7 . 1 2} \pm \mathbf{1 . 0 7}\end{array}$

${ }^{a}$ Weighted mean with $15 \%$ uncertainty propagated from the uncertainty in $k_{\text {ref }}$ (see the text).

times more abundant, ${ }^{16}$ consumption by $\mathrm{OH}$ will be about 5 times faster. However, in the $\mathrm{MBL}$ where $[\mathrm{Cl}]$ peaks in the range of $(1-3) \times 10^{5}$ molecules $\mathrm{cm}^{-3}, 17,18$ reaction 1 may dominate and can lead to lifetimes for $\mathrm{C}_{2} \mathrm{~F}_{4}$ as short as $\sim 0.6$ days. The precise magnitude of this short time will be sensitive to mixing, local conditions, and the time of day, but even this rough estimate indicates that the GWP of $\mathrm{C}_{2} \mathrm{~F}_{4}$ is negligible.

In our experiments, it proved impossible to remove all traces of oxygen, and the minimum pressure attained was 50 mbar (which is the specified performance of the multipass IR cell). The time history of the IR spectra showed consumption of $\mathrm{C}_{2} \mathrm{~F}_{4}$, of course, and the only other species noted was $\mathrm{CF}_{2} \mathrm{O}^{19}$ as its concentration increased. Initial and final spectra for an irradiated $\mathrm{C}_{2} \mathrm{~F}_{4} / \mathrm{Cl}_{2} / \mathrm{O}_{2}$ mixture are shown in Figure 2. We did not observe $\mathrm{CF}_{2} \mathrm{ClCF}_{2} \mathrm{Cl}$, which would be expected from reaction of the initial $\mathrm{Cl}+\mathrm{C}_{2} \mathrm{~F}_{4}$ adduct with $\mathrm{Cl}_{2}$. There must therefore be fast competing chemistry that cleaves the carbon atoms at room temperature, overcoming the $\mathrm{C}-\mathrm{C}$ bond dissociation enthalpy of $D_{298} \approx 295 \mathrm{~kJ} \mathrm{~mol}^{-1}$. ${ }^{20}$

In another experiment, we used this photochemical reaction to prepare $\mathrm{CF}_{2} \mathrm{O}$, separated it by low-temperature distillation, and calibrated the integrated IR intensity with a known partial pressure of $\mathrm{CF}_{2} \mathrm{O}$ in the IR cell. Propagation of reasonable experimental uncertainties suggests that this calibration is accurate to $\sim 5 \%$. When two different species are compared, ratios are likely accurate to about $7 \%$. Given our calibration, we deduce that $93 \pm 7 \%$ of the consumed $\mathrm{C}_{2} \mathrm{~F}_{4}$ is transformed to $\mathrm{CF}_{2} \mathrm{O}$.

We propose the following mechanism, where the reaction enthalpies at $298 \mathrm{~K}$ have been computed via the CBS-QB3 computational methodology. ${ }^{21}$ This incorporates approximate extrapolation of coupled cluster results to the complete basis set limit, at geometries determined with density functional theory (DFT), namely, B3LYP used with the $6-311 \mathrm{G}(2 \mathrm{~d}, \mathrm{~d}, \mathrm{p})$ atomic basis set. This level of DFT is also used for harmonic

Table 1. Initial Concentration of the Reactants, Integrated Spectral Regions, and Rate Coefficient Ratios $\left(k_{\mathrm{R}} / k_{\mathrm{ref}}\right)$ for the Reactions of $\mathrm{Cl}$ Radicals with Three Reactants $\mathrm{R}$ Relative to the Reference $\mathrm{C}_{4} \mathrm{~F}_{6}$ at $(293 \pm 2) \mathrm{K}$

\begin{tabular}{|c|c|c|c|c|c|}
\hline reactant & {$[\mathrm{R}]_{\mathrm{o}} / 10^{15}$ molecules $\mathrm{cm}^{-3}$} & integrated range $/ \mathrm{cm}^{-1}$ & {$[\mathrm{ref}]_{\mathrm{o}} / 10^{15}$ molecules $\mathrm{cm}^{-3}$} & integrated range $/ \mathrm{cm}^{-1}$ & $\left(k_{\mathrm{R}} / k_{\mathrm{ref}}\right) \pm \sigma$ \\
\hline \multirow[t]{2}{*}{$\mathrm{CF}_{2}=\mathrm{CF}_{2}$} & 2.77 & $1167-1200$ & 2.63 & $1312-1363$ & $0.813 \pm 0.011$ \\
\hline & 2.05 & & 1.95 & & $0.832 \pm 0.009$ \\
\hline \multirow[t]{2}{*}{$(E / Z)-\mathrm{CFCl}=\mathrm{CFCl}$} & 2.34 & $1155-1180$ & 2.90 & & $0.826 \pm 0.019$ \\
\hline & 1.79 & & 2.23 & & $0.803 \pm 0.018$ \\
\hline \multirow[t]{2}{*}{$\mathrm{CF}_{2}=\mathrm{CCl}_{2}$} & 2.68 & $1110-1150$ & 1.95 & & $0.916 \pm 0.010$ \\
\hline & 2.14 & & 1.56 & & $0.886 \pm 0.004$ \\
\hline
\end{tabular}




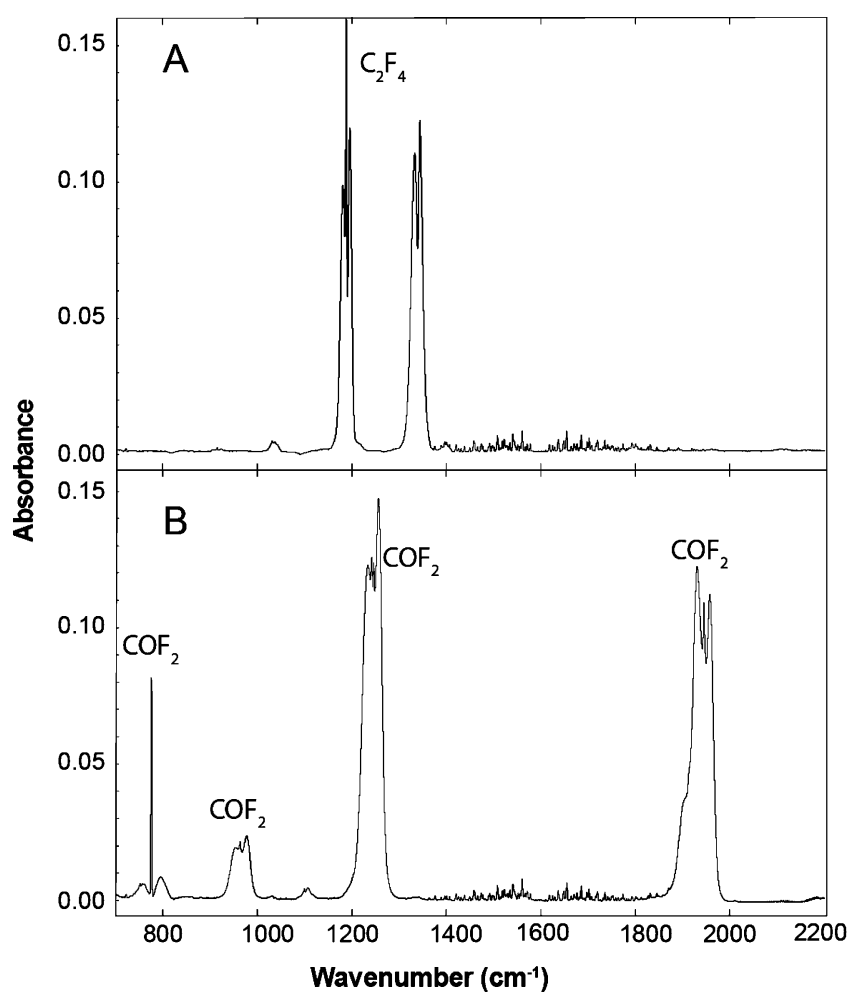

Figure 2. Initial and final infrared spectra for photolysis of a $\mathrm{Cl}_{2} / \mathrm{C}_{2} \mathrm{~F}_{4}$ mixture in the presence of $\mathrm{O}_{2}$. Absorbance is base 10 .

vibrational analysis and thermal corrections. These calculations were carried out with the Gaussian 09 program suite, ${ }^{22}$ and the computed structures and energies are provided in the Supporting Information. CBS-QB3 is not highly accurate, and we expect errors up to around $10 \mathrm{~kJ} \mathrm{~mol}^{-1}$, but this method provides an approximate assessment of enthalpies and barrier heights that are otherwise unavailable, including for the larger species considered below. In some cases, barrier heights are derived via searches for the saddle point along the reaction coordinate connecting the specified reactants and products. The geometry at this transition state (TS) is confirmed by visualization of the imaginary frequency that corresponds to motion along the reaction coordinate and in ambiguous cases is followed up by computation of the intrinsic reaction coordinate starting from the TS. The enthalpy at the TS relative to the reactants yields the barrier, which we evaluate here for $298 \mathrm{~K}$. The observed activation energy for a bimolecular reaction is typically larger by about $2 R T$. We comment that to be significant in atmospheric chemistry, which occurs at room temperature and below, proposed bimolecular reaction pathways cannot be significantly endothermic, and any barriers must be modest or negligible.

The initial step is addition of $\mathrm{Cl}$ to the $\pi$ bond

$$
\begin{gathered}
\mathrm{Cl}^{\bullet}+\mathrm{CF}_{2}=\mathrm{CF}_{2} \rightarrow \mathrm{CF}_{2} \mathrm{Cl}-\mathrm{CF}_{2}^{\bullet} \\
\Delta H_{298}=-146 \mathrm{~kJ} \mathrm{~mol}^{-1}
\end{gathered}
$$

followed by addition of oxygen

$$
\begin{gathered}
\mathrm{CF}_{2} \mathrm{Cl}-\mathrm{CF}_{2}^{\bullet}+\mathrm{O}_{2} \rightarrow \mathrm{CF}_{2} \mathrm{Cl}-\mathrm{CF}_{2} \mathrm{OO}^{\bullet} \\
\Delta \mathrm{H}_{298}=-152 \mathrm{~kJ} \mathrm{~mol}^{-1}
\end{gathered}
$$

We envisage two possible fates for this peroxy radical

$$
\begin{aligned}
& \mathrm{CF}_{2} \mathrm{Cl}-\mathrm{CF}_{2} \mathrm{OO}^{\bullet}+\mathrm{CF}_{2} \mathrm{Cl}-\mathrm{CF}_{2} \mathrm{OO}^{\bullet} \rightarrow 2 \mathrm{CF}_{2} \mathrm{Cl}-\mathrm{CF}_{2} \mathrm{O}^{\bullet}+\mathrm{O}_{2} \\
& \Delta \mathrm{H}_{298}=0 \mathrm{~kJ} \mathrm{~mol}^{-1} \\
& \mathrm{CF}_{2} \mathrm{Cl}-\mathrm{CF}_{2} \mathrm{OO}^{\bullet}+\mathrm{Cl}^{\bullet} \rightarrow \mathrm{CF}_{2} \mathrm{Cl}-\mathrm{CF}_{2} \mathrm{O}^{\bullet}+\mathrm{ClO}^{\bullet} \\
& \Delta \mathrm{H}_{298}=-15 \mathrm{~kJ} \mathrm{~mol}^{-1}
\end{aligned}
$$

The self-reaction of peroxy radicals is well-known, and at the high concentrations encountered in laboratory studies, reaction 13 is likely. The analogous self-reaction for $\mathrm{CF}_{3} \mathrm{OO}$ has a rate constant ${ }^{23}$ of $2.3 \times 10^{-12} \mathrm{~cm}^{3}$ molecule $\mathrm{s}^{-1} \mathrm{~s}^{-1}$, and we speculate that the rate constant for reaction 13 is similar. It is not expected to be important in the atmosphere, where the concentration of peroxy species will be much smaller than that in the laboratory experiments. An alternative path to the halogenated ethoxy species is $\mathrm{O}$ atom abstraction by a radical as in reaction 14. In our experiments, this may be carried out by $\mathrm{Cl}$ atoms, while in the atmosphere, $\mathrm{NO}$ is typically invoked for this role. ${ }^{4}$ As a specific example, the reactions of $\mathrm{CF}_{3} \mathrm{OO}$ with $\mathrm{Cl}$ and $\mathrm{NO}$ have rate constants of about $4 \times 10^{-11}$ and $2 \times$ $10^{-11} \mathrm{~cm}^{3}$ molecule $\mathrm{s}^{-1} \mathrm{~s}^{-1}$, respectively, at room temperature, ${ }^{24}$ which are within a factor of 10 of the collision rate so that any barriers are small. Driven by the high stability of $\mathrm{CF}_{2} \mathrm{O}$, the product ethoxy could dissociate

$$
\begin{gathered}
\mathrm{CF}_{2} \mathrm{Cl}-\mathrm{CF}_{2} \mathrm{O}^{\bullet} \rightarrow \mathrm{CF}_{2} \mathrm{Cl}^{\bullet}+\mathrm{CF}_{2} \mathrm{O} \\
\Delta \mathrm{H}_{298}=-35 \mathrm{~kJ} \mathrm{~mol}^{-1}
\end{gathered}
$$

Here the negative reaction enthalpy indicates that the halogenated ethoxy radical is metastable, by contrast to hydrocarbon alkoxy radicals. Our computations predict a long $\mathrm{C}-\mathrm{C}$ bond in this haloethoxy species, $1.62 \times 10^{-10} \mathrm{~m}$, and a barrier to dissociation was located via DFT at a C-C separation of $1.87 \times 10^{-10} \mathrm{~m}$. The enthalpy barrier at $298 \mathrm{~K}$ relative to $\mathrm{CF}_{2} \mathrm{ClCF}_{2} \mathrm{O}$ is $9 \mathrm{~kJ} \mathrm{~mol}^{-1}$ via the $\mathrm{CBS}-\mathrm{QB} 3$ method. This low barrier implies a high rate constant for reaction 15 . Indeed, dissociation could be concerted with reactions 13 or 14 .

The subsequent fate of $\mathrm{CF}_{2} \mathrm{Cl}$ is rapid reaction with $\mathrm{O}_{2}$, which has been studied in detail by Codnia and Azcárate. ${ }^{25}$ There are two channels that at $298 \mathrm{~K}$ and 1 bar contribute approximately equally

$$
\mathrm{CF}_{2} \mathrm{Cl}^{\bullet}+\mathrm{O}_{2} \rightarrow \mathrm{CF}_{2} \mathrm{ClOO}^{\bullet} \quad \Delta H_{298}=-150 \mathrm{~kJ} \mathrm{~mol}^{-1}
$$

$$
\begin{gathered}
\mathrm{CF}_{2} \mathrm{Cl}^{\bullet}+\mathrm{O}_{2} \rightarrow \mathrm{CF}_{2} \mathrm{O}+\mathrm{ClO}^{\bullet} \\
\Delta H_{298}=-223 \mathrm{~kJ} \mathrm{~mol}^{-1}
\end{gathered}
$$

The $\mathrm{CF}_{2} \mathrm{ClOO}$ peroxy species may react analogously to $\mathrm{CF}_{2} \mathrm{ClCF}_{2} \mathrm{OO}^{\circ}$, that is, via

$$
\begin{gathered}
\mathrm{CF}_{2} \mathrm{ClOO}^{\bullet}+\mathrm{CF}_{2} \mathrm{ClOO}^{\bullet} \rightarrow 2 \mathrm{CF}_{2} \mathrm{ClO}^{\bullet}+\mathrm{O}_{2} \\
\Delta \mathrm{H}_{298}=+35 \mathrm{~kJ} \mathrm{~mol}^{-1} \\
\mathrm{CF}_{2} \mathrm{ClOO}^{\bullet}+\mathrm{Cl}^{\bullet} \rightarrow \mathrm{CF}_{2} \mathrm{ClO}^{\bullet}+\mathrm{ClO}^{\bullet} \\
\Delta H_{298}=+3 \mathrm{~kJ} \mathrm{~mol}^{-1}
\end{gathered}
$$

The endothermicity of reaction 18 suggests that reaction 19 may be the dominant path, unless the self-reaction is concerted with exothermic $\mathrm{Cl}$-atom elimination

$$
\mathrm{CF}_{2} \mathrm{ClO}^{\bullet} \rightarrow \mathrm{CF}_{2} \mathrm{O}+\mathrm{Cl}^{\bullet} \quad \Delta H_{298}=-75 \mathrm{~kJ} \mathrm{~mol}^{-1}
$$


Our calculations indicate that the TS for reaction 20 is at a $\mathrm{C}-\mathrm{Cl}$ distance of $2.01 \times 10^{-10} \mathrm{~m}$. The $298 \mathrm{~K}$ enthalpy barrier to dissociation computed at this geometry is $-26 \mathrm{~kJ} \mathrm{~mol}^{-1}$ (CBS-QB3). Whether $\mathrm{CF}_{2} \mathrm{ClO}$ is metastable or in fact unstable, clearly it will dissociate rapidly. Overall, therefore, reactions 11-20 provide a fast pathway for the overall $\mathrm{Cl}$-atom-catalyzed oxidation of $\mathrm{C}_{2} \mathrm{~F}_{4}$

$$
\begin{gathered}
\mathrm{Cl}+\mathrm{C}_{2} \mathrm{~F}_{4}+\mathrm{O}_{2} \rightarrow \mathrm{Cl}+2 \mathrm{CF}_{2} \mathrm{O} \\
\Delta \mathrm{H}_{298}=-541 \mathrm{~kJ} \mathrm{~mol}^{-1}
\end{gathered}
$$

3.2. Rate Constant and Oxidation Products of $(E / Z)$ $\mathrm{CFCl}=\mathrm{CFCl}$. The mixture of isomers was monitored via absorbance in the region of $1150-1180 \mathrm{~cm}^{-1}$, which is common to both species. ${ }^{26}$ There are two minor unique peaks, but one is obscured by the absorption spectra of the products (see Figure 3), and therefore, it was not possible to

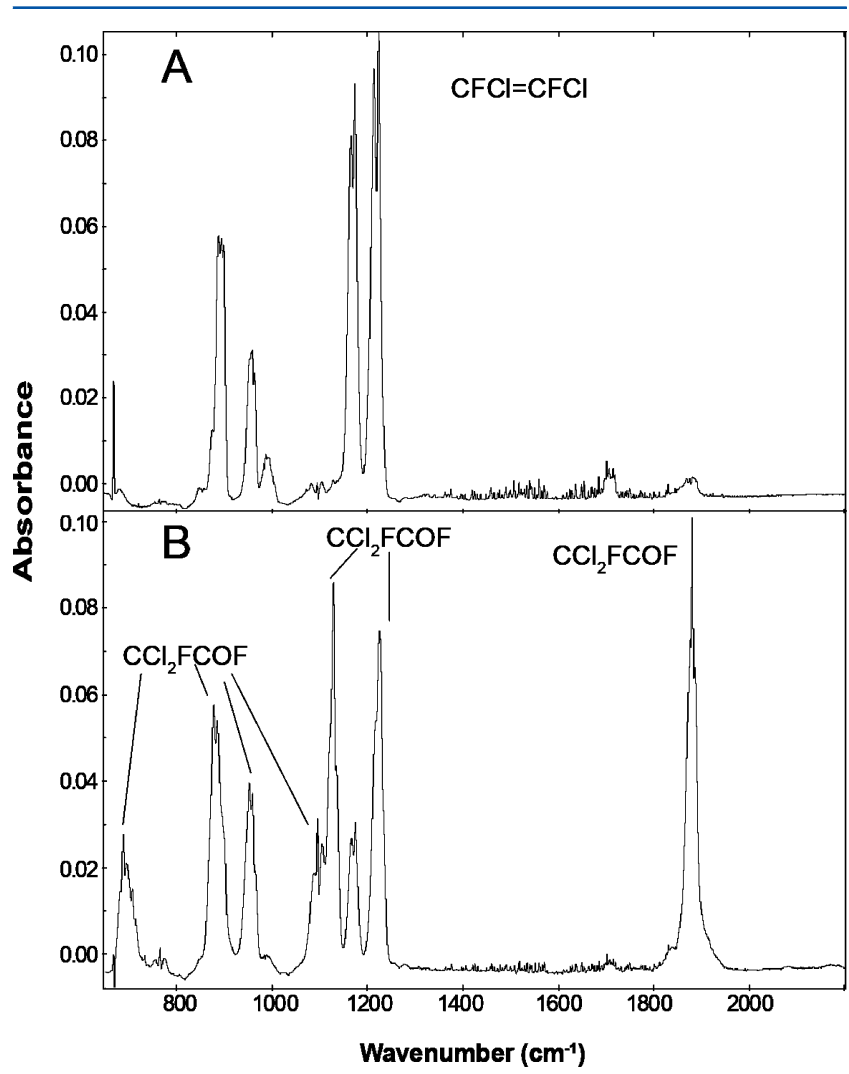

Figure 3. Initial and final infrared spectra for photolysis of a $\mathrm{Cl}_{2} /$ $\mathrm{CFClCFCl}$ mixture in the presence of $\mathrm{O}_{2}$. Absorbance is base 10 .

resolve the kinetics of individual cis or trans isomers. We dissolved some of our $\mathrm{CFClCFCl}$ in $\mathrm{CDCl}_{3}(\mathrm{l})$ and used ${ }^{19} \mathrm{~F}$ $\mathrm{NMR}^{27}$ to determine an initial composition of $51 \pm 2 \%$ cis isomer. The effective overall rate constant for reaction of this mixture with $\mathrm{Cl}$ is $k_{2}=(6.5 \pm 1.0) \times 10^{-11} \mathrm{~cm}^{3}$ molecule ${ }^{-1} \mathrm{~s}^{-1}$, very similar to that for $\mathrm{C}_{2} \mathrm{~F}_{4}$ and in accord with the value of (5.4 $\pm 1.3) \times 10^{-11} \mathrm{~cm}^{3}$ molecule $\mathrm{e}^{-1} \mathrm{~s}^{-1}$ obtained recently by Barrera et al. ${ }^{28}$ Similar remarks therefore apply to the atmospheric lifetime with respect to reaction 2 . This lifetime will be even shorter in the presence of hydroxyl, but it is already clear that the GWP is minor. We observed dichlorofluoroacetyl fluoride $\left(\mathrm{CCl}_{2} \mathrm{FCFO}\right)$ in the product spectrum in Figure $3 \mathrm{~B}$, assigned by comparison with the published spectrum.
Reaction 2 may also lead to $\mathrm{COFCl}$ whose spectrum, ${ }^{30}$ if it is present in modest quantities, would be largely overlapped. $\mathrm{COFCl}$ could be formed analogously to the mechanism proposed above for $\mathrm{C}_{2} \mathrm{~F}_{4}$, but Sanhueza and Heicklen, who conducted similar experiments to ours by photolyzing $\mathrm{Cl}_{2} / \mathrm{O}_{2} /$ $\mathrm{CFClCFCl}$ mixtures, ${ }^{31}$ reported no formation of $\mathrm{COFCl}$ and instead assigned $\mathrm{CFCl}_{2} \mathrm{CFO}$ as the exclusive product. A question therefore is why is this reaction different from reaction 1 ? We have analyzed two potential decomposition pathways of the likely intermediate

$$
\begin{gathered}
\mathrm{CCl}_{2} \mathrm{FCFClO}^{\bullet} \rightarrow \mathrm{CFCl}_{2}^{\bullet}+\mathrm{COFCl} \\
\Delta H_{298}=-32 \mathrm{~kJ} \mathrm{~mol}^{-1} \\
\mathrm{CCl}_{2} \mathrm{FCFClO}^{\bullet} \rightarrow \mathrm{CCl}_{2} \mathrm{FCFO}+\mathrm{Cl}^{\bullet} \\
\Delta \mathrm{H}_{298}=-24 \mathrm{~kJ} \mathrm{~mol}^{-1}
\end{gathered}
$$

At the CBS-QB3 level of theory, the reaction enthalpies indicate that the halogenated ethoxy intermediate is metastable with respect to both pathways. Accordingly, we characterized the TSs. The enthalpy barriers at $298 \mathrm{~K}$ are 22 and $6 \mathrm{~kJ} \mathrm{~mol}^{-1}$, respectively, for reactions 22 and 23, and therefore, kinetic control of the decomposition of the ethoxy intermediate favors loss of the $\mathrm{Cl}$ atom and formation of the observed $\mathrm{CCl}_{2} \mathrm{FCFO}$.

In the absence of oxygen, we would expect the product to be $\mathrm{CFCl}_{2} \mathrm{CFCl}_{2}$ (CFC-112) from interception of the initial $\mathrm{CFCl}_{2} \mathrm{CFCl}^{\bullet}$ radical by $\mathrm{Cl}_{2}$ rather than by $\mathrm{O}_{2}$. The integrated absorption cross section of CFC-112 was published by Oliff and Fischer in 1994, but not the spectrum. In 2014, Etminan et al. ${ }^{32}$ examined the spectrum at high resolution but were unable to obtain a pure sample. We synthesized CFC- 112 via $4 \mathrm{~h}$ of photolysis of a mixture of $10 \mathrm{mbar}$ of $\mathrm{Cl}_{2}$ and $0.7 \mathrm{mbar}$ of $\mathrm{CFClCFCl}$, followed by freeze-pump-thaw purification at 77 $\mathrm{K}$ and distillation from $273 \mathrm{~K}$. The spectrum is shown in Figure 4. The main difference from the Etminan et al. spectrum of a mixture of CFC-112 and CFC-112a is the absence of their peak at $1170 \mathrm{~cm}^{-1}$. The likely impact on the calculated radiative forcing is modest. While this work was in progress, a new spectrum was published by Davis et al. ${ }^{33}$ Our spectrum is in

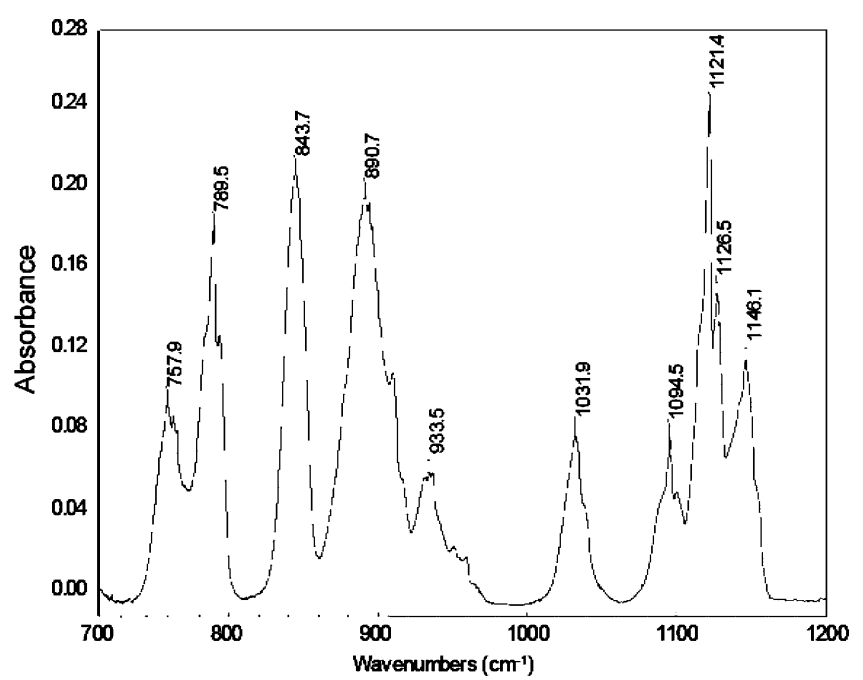

Figure 4. Infrared spectrum of CFC-112. The conditions were 0.4 mbar of $\mathrm{CFCl}_{2} \mathrm{CFCl}_{2}$ diluted in $800 \mathrm{mbar}$ of $\mathrm{Ar}, 1000$ scans at 0.25 $\mathrm{cm}^{-1}$ resolution, path length of $2.4 \mathrm{~m}$, at $290 \pm 2 \mathrm{~K}$. Absorbance is base 10 . 
good accord, with the same peak locations and leading to a radiative efficiency (RE) of $0.32 \mathrm{~W} \mathrm{~m}^{-2} \mathrm{ppb}^{-1}$, in agreement with the value of $0.28 \mathrm{~W} \mathrm{~m}^{-2} \mathrm{ppb}^{-1}$ determined by Davis et al.

3.3. Rate Constant and Oxidation Products of $\mathrm{CCl}_{2}=$ $\mathrm{CF}_{2}$. Our measured rate constant is $k_{3}=(7.1 \pm 1.1) \times 10^{-11}$ $\mathrm{cm}^{3}$ molecule $\mathrm{s}^{-1} \mathrm{~s}^{-1}$, and therefore, reaction 3 is another example of a rate constant that is close to the hard-sphere collision value. This value agrees with the determination of $(6.3$ $\pm 1.5) \times 10^{-11} \mathrm{~cm}^{3}$ molecule ${ }^{-1} \mathrm{~s}^{-1}$ by Barrera et al. ${ }^{28}$ Infrared spectra of mixtures with $\mathrm{Cl}_{2}$ and $\mathrm{O}_{2}$ before and after $\mathrm{UV}$ photolysis are shown in Figure 5. The major product peaks are

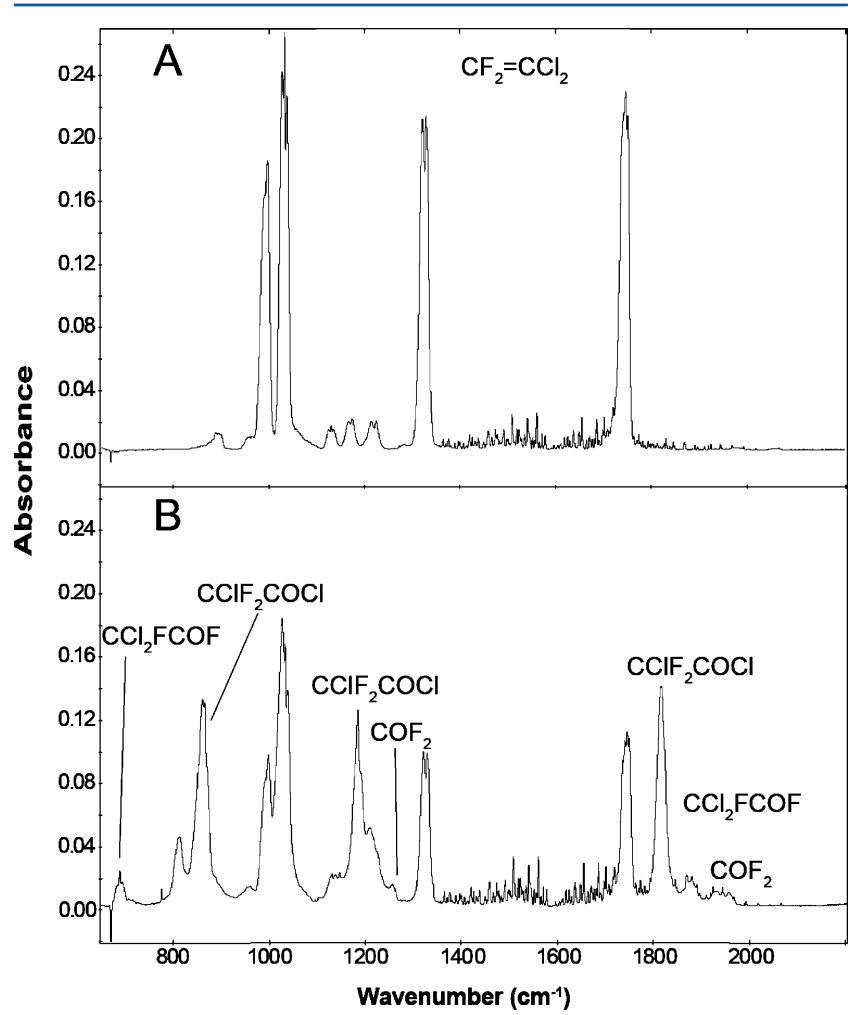

Figure 5. Initial and final infrared spectra for photolysis of a $\mathrm{Cl}_{2} /$ $\mathrm{CCl}_{2} \mathrm{CF}_{2}$ mixture in the presence of $\mathrm{O}_{2}$. Absorbance is base 10 .

assigned to chlorodifluoroacetyl chloride, $\mathrm{CClF}_{2} \mathrm{CClO}^{34} \mathrm{~A}$ plausible pathway is initial $\mathrm{Cl}$ addition at the $\mathrm{CF}_{2}$ end, allowing for formation of a $\mathrm{CClF}_{2} \mathrm{CCl}_{2} \mathrm{OO}$ peroxy radical that is transformed to $\mathrm{CClF}_{2} \mathrm{CCl}_{2} \mathrm{O}$ and forms the acetyl chloride by loss of a $\mathrm{Cl}$ atom. ${ }^{31}$ Minor peaks of $\mathrm{COF}_{2}$ are also visible in Figure $5 \mathrm{~B}$, which we attribute to addition of $\mathrm{Cl}$ to the $\mathrm{CCl}_{2}$ end of the molecule. This will form a radical center at the $\mathrm{CF}_{2}$ end, and chemistry similar to that proposed for $\mathrm{C}_{2} \mathrm{~F}_{4}$ can lead to $\mathrm{COF}_{2}$. The observed yield is $\sim 3.6 \%$ of that seen from $\mathrm{C}_{2} \mathrm{~F}_{4}$, from which we deduce the ratio for attack at the $\mathrm{Cl} / \mathrm{F}$ ends of $\mathrm{CCl}_{2}=\mathrm{CF}_{2}$ to be about 0.04:0.96. There are also small peaks from $\mathrm{CCl}_{2} \mathrm{FCFO}$ in Figure $5 \mathrm{~B}$, which we attribute to reaction of $\mathrm{CFClCFCl}$ which from Figure $5 \mathrm{~A}$ makes up $\sim 8 \%$ of the $\mathrm{CCl}_{2} \mathrm{CF}_{2}$ sample.

3.4. Oxidation Products of $\mathrm{CF}_{2}=\mathrm{CF}-\mathrm{CF}=\mathrm{CF}_{2}$. Two major products were identified from the spectrum in Figure $6 \mathrm{~B}$. One is $\mathrm{CF}_{2} \mathrm{O}$, and the other is the epoxy compound $\mathrm{OCF}_{2} \mathrm{CFC}(\mathrm{F})=\mathrm{O}$ where the first $\mathrm{O}$ atom is bonded to both of the first two $\mathrm{C}$ atoms. This 2,3-epoxyperfluoropropionylfluoride species has been noted before in the mercury-sensitized photolysis of $\mathrm{O}_{2} / \mathrm{CF}_{2}=\mathrm{CF}-\mathrm{CF}=\mathrm{CF}_{2}$ mixtures. ${ }^{35}$ The pub-

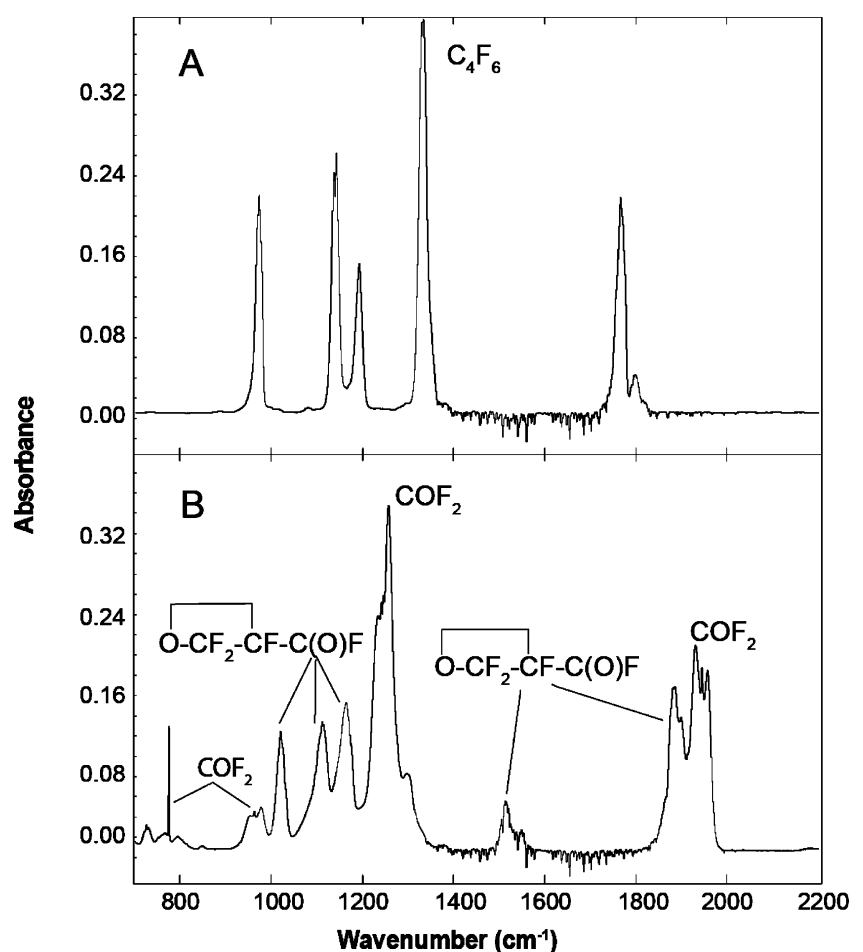

Figure 6. Initial and final infrared spectra for photolysis of a $\mathrm{Cl}_{2} / \mathrm{C}_{4} \mathrm{~F}_{6}$ mixture in the presence of $\mathrm{O}_{2}$. Absorbance is base 10 .

lished IR spectrum is of low resolution. Accordingly, we prepared a sample photochemically via UV photolysis for $1.5 \mathrm{~h}$ of a mixture of $0.7 \mathrm{mbar}$ of $\mathrm{CF}_{2}=\mathrm{CF}-\mathrm{CF}=\mathrm{CF}_{2}, 4 \mathrm{mbar}$ of $\mathrm{O}_{2}$, and $1.6 \mathrm{mbar}$ of $\mathrm{Cl}_{2}$, which was then put through freezepump-thaw cycles at 77 and $195 \mathrm{~K}$. The spectrum is shown in Figure 7. On the basis of the IR absorbances, we estimate yields of $66 \pm 5 \% \mathrm{CF}_{2} \mathrm{O}$ and $38 \pm 3 \% \mathrm{OCF}_{2} \mathrm{CFC}(\mathrm{F})=\mathrm{O}$.

We can speculate about the mechanism leading to the epoxy product. Stuckey et al. ${ }^{35}$ suggested that in their mercurysensitized $\mathrm{O}_{2} / \mathrm{C}_{4} \mathrm{~F}_{6}$ system energy was transferred first to $\mathrm{O}_{2}$ and then to $\mathrm{C}_{4} \mathrm{~F}_{6}$, which then reacted with $\mathrm{O}_{2}$ to yield triplet

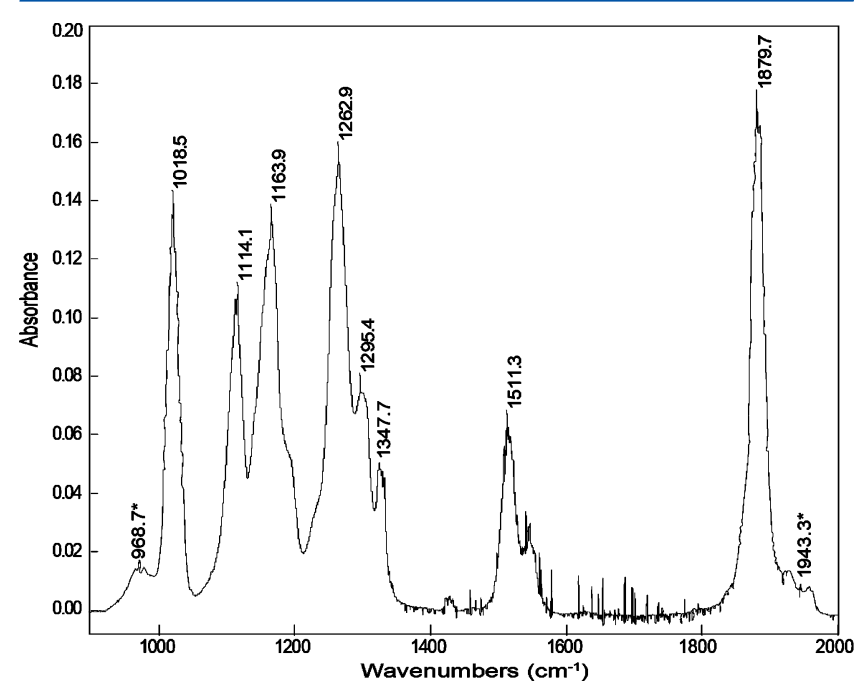

Figure 7. Infrared spectrum of 2,3-epoxyperfluoropropionylfluoride. The conditions were $0.5 \mathrm{mbar}$ of $\mathrm{OCF}_{2} \mathrm{CFC}(\mathrm{F}) \mathrm{O}$ diluted in $270 \mathrm{mbar}$ of $\mathrm{Ar}, 6000$ scans at $0.5 \mathrm{~cm}^{-1}$ resolution, path length of $2.4 \mathrm{~m}$, at $290 \pm$ $2 \mathrm{~K}$. Absorbance is base 10 . Impurity peaks are marked with an *. 


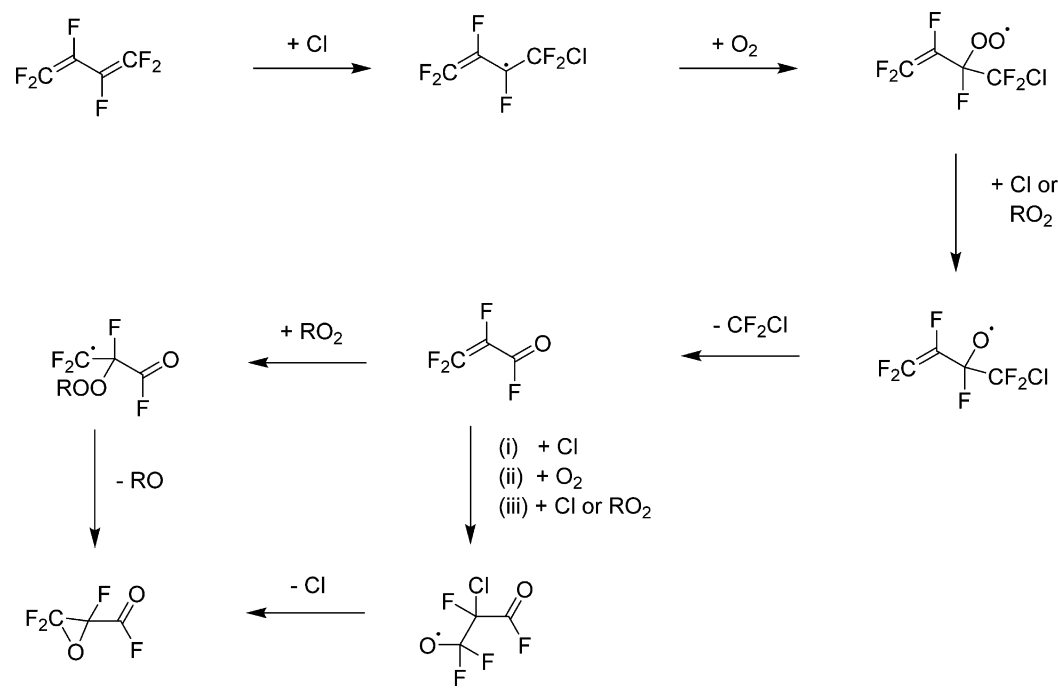

Figure 8. Possible reaction scheme leading to 2,3-epoxyperfluoropropionylfluoride.

Table 3. Lifetime in Days of Fluoro-olefins with Respect to Tropospheric $\mathrm{Cl}$ and $\mathrm{OH}$ Attack

\begin{tabular}{|c|c|c|c|c|}
\hline species & $\begin{array}{l}{[\mathrm{Cl}]=3 \times 10^{5}} \\
\text { molecules } \mathrm{cm}^{-3}\end{array}$ & $\begin{array}{l}{[\mathrm{Cl}]=3 \times 10^{4}} \\
\text { molecules } \mathrm{cm}^{-3}\end{array}$ & $\begin{array}{l}{[\mathrm{OH}]=1 \times 10^{6}} \\
\text { molecules } \mathrm{cm}^{-3}\end{array}$ & {$[\mathrm{Cl}]=\underset{\text { molecules } \mathrm{cm}^{-3}}{3 \times 10^{4} \text { and }[\mathrm{OH}]}=1 \times 10^{6}$} \\
\hline $\mathrm{C}_{2} \mathrm{~F}_{4}$ & 0.6 & 5.8 & 1.1 & 0.9 \\
\hline $\mathrm{CFClCFCl}$ & 0.6 & 5.9 & 7.2 & 3.2 \\
\hline $\mathrm{CCl}_{2} \mathrm{CF}_{2}$ & 0.5 & 5.4 & 2.3 & 1.6 \\
\hline $\mathrm{C}_{4} \mathrm{~F}_{6}$ & 0.5 & 4.8 & 1.1 & 0.9 \\
\hline
\end{tabular}

$\mathrm{CF}_{2}$ and the diradical $\mathrm{CF}_{2}=\mathrm{CFCF}(\mathrm{F}) \mathrm{OO}$, which might rearrange by either of two pathways to the final product. Here we note that Cl-catalyzed chemistry of the kind proposed above could accomplish the same transformation, which we illustrate in Figure 8. We can imagine two pathways from a possible ketone intermediate to the final epoxy product. One has a second round of $\mathrm{Cl}$ atom addition followed by $\mathrm{O}_{2}$ addition and reaction to an alkoxy radical, which could ringclose in concert with $\mathrm{C}-\mathrm{Cl}$ bond fission. The other pathway involves addition of an $\mathrm{RO}_{2}$ peroxy radical followed by loss of $\mathrm{RO}$ concerted with ring closure.

We have carried out ab initio calculations on these pathways. CBS-QB3 theory indicates that the TS connecting $\mathrm{F}_{2} \mathrm{C}\left(\mathrm{O}^{\bullet}\right)-$ $\mathrm{CFCl}-\mathrm{CF}=\mathrm{O}$ to the final product is $111 \mathrm{~kJ} \mathrm{~mol}^{-1}$ above the reactant and that 2,3-epoxyperfluoropropionylfluoride lies $65 \mathrm{~kJ}$ $\mathrm{mol}^{-1}$ above the alkoxy intermediate. The other proposed mechanism involves $\mathrm{RO}_{2}$ addition to a double bond. We investigated a simplified model system

$\mathrm{CF}_{2}=\mathrm{CFH}+\mathrm{HO}_{2} \rightarrow \mathrm{CF}_{2} \cdot-\mathrm{CFH}(\mathrm{OOH}) \rightarrow \mathrm{CF}_{2}-\mathrm{CFH}+\mathrm{OH}$

with CBS-QB3 theory and found favorable thermochemistry. The two steps are exothermic by 58 and $108 \mathrm{~kJ} \mathrm{~mol}^{-1}$, respectively. However, the enthalpy barrier to the first step is 53 $\mathrm{kJ} \mathrm{mol}^{-1}$, which will make it too slow to be important. Thus, at present, we do not have a plausible mechanism that is also supported by ab initio results.

3.5. Atmospheric Lifetimes and Global Warming Potentials (GWPs). Table 3 summarizes the lifetimes of the four fluoro-olefins with respect to different atmospheric processes, namely, attack by $\mathrm{Cl}$ atoms in the $\mathrm{MBL}$ with $[\mathrm{Cl}]$ taken to be $3 \times 10^{5}$ molecules $\mathrm{cm}^{-3}$, attack by $\mathrm{Cl}$ in the general troposphere with $[\mathrm{Cl}] \approx 3 \times 10^{4}$ molecules $\mathrm{cm}^{-3}$, attack by tropospheric $\mathrm{OH}^{12}$ with $[\mathrm{OH}]=1 \times 10^{6}$ molecules $\mathrm{cm}^{-3}$, and the combined effect of $\mathrm{Cl}$ and $\mathrm{OH}$ in the troposphere. It may be seen that when averaged across the troposphere, the lifetime is controlled mainly by reaction with $\mathrm{OH}$ (although $\mathrm{Cl}$ reaction is comparably fast for $\mathrm{CFClCFCl}$ ) but that in the special case of the MBL the $\mathrm{Cl}$ atom chemistry is much faster. Table 4 lists

Table 4. Radiative Efficiency (RE), RE Correction Factor $(f)$, and Global Warming Potential (GWP) for Fluoroolefins

\begin{tabular}{lccc}
\multicolumn{1}{c}{ species } & $\mathrm{RE} / \mathrm{W} \mathrm{m}^{-2} \mathrm{ppb}^{-1}$ & $f$ & $\mathrm{GWP}$ \\
$\mathrm{C}_{2} \mathrm{~F}_{4}$ & 0.50 & 0.013 & 0.012 \\
$\mathrm{CFClCFCl}$ & 0.36 & 0.036 & 0.054 \\
$\mathrm{CCl}_{2} \mathrm{CF}_{2}$ & 0.35 & 0.019 & 0.014 \\
$\mathrm{C}_{4} \mathrm{~F}_{6}$ & 0.56 & 0.013 & 0.008 \\
\hline
\end{tabular}

REs and 100 year GWPs computed via the method of Hodnebrog et al. ${ }^{36}$ Given that our RE for CFC-112 was shown to agree to within $\sim 15 \%$ of that from Davis et al., ${ }^{33}$ we suggest $15 \%$ as an uncertainty for all of the RE values. The uncertainty in the lifetime is also $\sim 15 \%$ based on the uncertainty that we proposed for $k_{\text {ref. }}$ Taking these in quadrature yields an uncertainty of $\sim 20 \%$ for our GWP values. We note that inclusion of the multiplicative correction factor $f$, which arises from the nonuniform atmospheric distribution of short-lived species, ${ }^{36}$ makes the already small GWPs entirely negligible and on the order of 0.01 .

\section{CONCLUSIONS}

The rate constants for reactions of simple halogenated ethenes with photolytically-generated chlorine atoms have been characterized, along with site-specific information and identification of major products in the presence of oxygen, via infrared spectroscopy. Photolysis was also employed prepara- 
tively and the medium-resolution spectra of two products, not previously available, are presented. $\mathrm{CF}_{2}$ and $\mathrm{CFCl}$ sites appear to be more reactive than $\mathrm{CCl}_{2}$ sites toward addition of $\mathrm{Cl}$. The results show that the $\mathrm{Cl}$ atom kinetics alone, even before consideration of rapid removal by $\mathrm{OH}$, are sufficient to ensure that these chlorofluoro ethenes have small GWPs. Accordingly, in the context of radiative forcing, they could make potential environmentally benign substitutes for current refrigerants.

\section{ASSOCIATED CONTENT}

\section{S Supporting Information}

The Supporting Information is available free of charge on the ACS Publications website at DOI: 10.1021/acs.jpca.6b05305.

Two tables listing computed coordinates and enthalpies of species and transition states considered in the mechanisms for $\mathrm{C}_{2} \mathrm{~F}_{4}, \mathrm{CFClCFCl}$, and $\mathrm{C}_{4} \mathrm{~F}_{6}$ (PDF)

\section{AUTHOR INFORMATION}

\section{Corresponding Author}

*E-mail: marshall@unt.edu.

\section{Notes}

The authors declare no competing financial interest.

\section{ACKNOWLEDGMENTS}

We thank Prof. M. G. Richmond and Dr. Li Yang for the NMR analysis and the referees for valuable comments. Assistance in the laboratory was provided by Ryan McCann, Eurielle Nkamssi, Kejun Shao, Joe Watson, and Malcom Zimmerman. This work was supported by the Robert A. Welch Foundation (Grant B-1174), and E.C.C. also thanks the Texas Academy of Mathematics and Science for support.

\section{REFERENCES}

(1) Brasseur, G. P.; Orlando, J. J.; Tyndall, G. S. Atmospheric Chemistry and Global Change; Oxford University Press: New York, 1999.

(2) Finlayson-Pitts, B. J.; Pitts, J. N., Jr. Chemistry of the Upper and Lower Atmosphere; Academic: San Diego, CA, 2000.

(3) Reisch, M. S. Propellants Under Pressure. Chem. Eng. News 2015, 93, 15-16.

(4) Wallington, T. J.; Sulbaek Andersen, M. P.; Nielsen, O. J. Atmospheric Chemistry of Short-Chain Haloolefins: Photochemical Ozone Creation Potentials (POCPs), Global Warming Potentials (GWPs), and Ozone Depletion Potentials (ODPs). Chemosphere 2015, 129, 135-141.

(5) Wallington, T. J.; Hurley, M. D. Atmospheric Chemistry of Hexafluorocyclobutene, Octafluorocyclopentene, and Hexafluoro-1,3butadiene. Chem. Phys. Lett. 2011, 507, 19-23.

(6) Spicer, C. W.; Chapman, E. G.; Finlayson-Pitts, B. J.; Plastridge, R. A.; Hubbe, J. M.; Fast, J. D.; Berkowitz, C. M. Unexpectedly High Concentrations of Molecular Chlorine in Coastal Air. Nature 1998, 394, 353-356.

(7) Hunadi, R. J.; Baum, K. Tetrafluoroethylene: A Convenient Laboratory Preparation. Synthesis 1982, 1982, 454.

(8) Atkinson, R. Kinetics and Mechanisms of the Gas-Phase Reactions of the Hydroxyl Radical with Organic Compounds under Atmospheric Conditions. Chem. Rev. 1986, 86, 69-201.

(9) Hwang, C.-J.; Jiang, R.-C.; Su, T.-M. Measurements of the Diffusion Coefficients of Atomic Chlorine in Rare Gases. J. Chem. Phys. 1986, 84, 5095-5100.

(10) Zemansky, M. W. Radii and Collision Probabilities of Mestastable Neon and Mercury Atoms. Phys. Rev. 1929, 34, 213-226.

(11) Mitchell, A. C. G.; Zemansky, M. W. Resonance Radiation and Excited Atoms; Cambridge University Press: London, 1934.
(12) Burkholder, J. B.; Sander, S. P.; Abbatt, J.; Barker, J. R.; Huie, R. E.; Kolb, C. E.; Kurylo, M. J.; Orkin, V. L.; Wilmouth, D. M.; Wine, P. H. Chemical Kinetics and Photochemical Data for Use in Atmospheric Studies, Evaluation No. 18. Publication 15-10; Jet Propulsion Laboratory: Pasadena, CA, 2015; http://jpldataeval.jpl.nasa.gov.

(13) Bevington, P. R. Data Reduction and Error Analysis for the Physical Sciences; McGraw-Hill: New York, 1969; p 88.

(14) Wingenter, O. W.; Sive, B. C.; Blake, N. J.; Blake, D. R.; Rowland, F. S. Atomic Chlorine Concentrations Derived from Ethane and Hydroxyl Measurements over the Equatorial Pacific Ocean: Implication for Dimethyl Sulfide and Bromine Monoxide. J. Geophys. Res. 2005, 110, D20308.

(15) Orkin, V. L.; Louis, F.; Huie, R. E.; Kurylo, M. J. Photochemistry of Bromine-Containing Fluorinated Alkenes: Reactivity toward OH and UV Spectra. J. Phys. Chem. A 2002, 106, 1019510199.

(16) Prinn, R. G.; Weiss, R. F.; Miller, B. R.; Huang, J.; Alyea, F. N.; Cunnold, D. M.; Fraser, P. J.; Hartley, D. E.; Simmonds, P. G. Atmospheric Trends and Lifetime of $\mathrm{CH}_{3} \mathrm{CCI}_{3}$ and Global $\mathrm{OH}$ Concentrations. Science 1995, 269, 187-192.

(17) Chang, C. T.; Liu, T. H.; Jeng, F. T. Atmospheric Concentration of the $\mathrm{Cl}$ Atom, ClO Radical, and HO Radical in the Coastal Marine Boundary Layer. Environ. Res. 2004, 94, 67-74.

(18) Pechtl, S.; von Glasow, R. Reactive Chlorine in the Marine Boundary Layer in the Outflow of Polluted Continental Air: A Model Study. Geophys. Res. Lett. 2007, 34, L11813.

(19) Mallinson, P. D.; McKean, D. C.; Holloway, J. H.; Oxton, I. A. Infrared Spectra of Carbonyl Fluorides and General Harmonic Force Field. Spectrochimica Acta Part A 1975, 31, 143-159.

(20) NIST-JANAF Thermochemical Tables; 4th ed.; Chase, M. W., Jr., Ed.; American Chemical Society and the American Institute of Physics: Woodbury, NY, 1998.

(21) Montgomery, J. A., Jr.; Frisch, M. J.; Ochterski, J. W.; Petersson, G. A. A Complete Basis Set Model Chemistry. VI. Use of Density Functional Geometries and Frequencies. J. Chem. Phys. 1999, 110, $2822-2827$.

(22) Frisch, M. J.; Trucks, G. W.; Schlegel, H. B.; Scuseria, G. E.; Robb, M. A.; Cheeseman, J. R.; Scalmani, G.; Barone, V.; Mennucci, B.; Petersson, G. A. et al. Gaussian 09; Gaussian, Inc.: Wallingford, CT, 2009.

(23) Sehested, J.; Mogelberg, T.; Fagerstrom, K.; Mahmoud, G.; Wallington, T. J. Absolute Rate Constants for the Self Reactions of $\mathrm{HO}_{2}, \mathrm{CF}_{3} \mathrm{CFHO}_{2}$, and $\mathrm{CF}_{3} \mathrm{O}_{2}$ Radicals and the Cross Reactions of $\mathrm{HO}_{2}$ with $\mathrm{FO}_{2}, \mathrm{HO}_{2}$ with $\mathrm{CF}_{3} \mathrm{CFHO}_{2}$, and $\mathrm{HO}_{2}$ with $\mathrm{CF}_{3} \mathrm{O}_{2}$ at $295 \mathrm{~K}$. Int. J. Chem. Kinet. 1997, 29, 673-682.

(24) Florent, L.; Burgess, D. R., Jr.; Rayez, M.-T.; Sawerysyn, J.-P. Kinetic Study of the Reactions of $\mathrm{CF}_{3} \mathrm{O}_{2}$ Radicals with $\mathrm{Cl}$ and NO. Phys. Chem. Chem. Phys. 1999, 1, 5087-5096.

(25) Codnia, J.; Azcárate, M. L. Rate Measurement of the Reaction of $\mathrm{CF}_{2} \mathrm{Cl}$ Radials with $\mathrm{O}_{2}$. Photochem. Photobiol. 2006, 82, 755-762.

(26) Craig, N. C.; Evans, D. A. Infrared and Raman Spectra of cisand trans-1,2-Dichloro-1,2-Difluoroethylene. J. Am. Chem. Soc. 1965, $87,4223-4230$

(27) Tiers, G. V. D.; Lauterbur, P. C. Fluorine NMR Spectroscopy. $\mathrm{X}$. Satellites in the Spectra of Cis- and Trans-CFCl=CFCl. Assignment of Coupling Constants for Fluorinated Olefins. J. Chem. Phys. 1962, 36, 1110-1111.

(28) Barrera, J. A.; Dalmasso, P. R.; Aranguren Abrate, J. P.; Taccone, R. A.; Lane, S. I. Kinetic Study of the $\mathrm{OH}$ and Cl-Initiated Oxidation, Lifetimes and Atmospheric Acceptability Indices of Three Halogenated Ethenes. RSC Adv. 2015, 5, 73501-73509.

(29) Guirgis, G. A.; Jin, Y.; Klaeboe, P.; Durig, J. R. Infrared and Raman Spectra, Conformational Stability, Barriers to Internal Rotation, $\mathrm{Ab}$ Initio Calculations and Vibrational Assignments for Dichlorofluoroacetyl Fluoride. Chem. Phys. 1997, 223, 131-148.

(30) Schriver, L.; Abdelaoui, O.; Schriver, A. Atmospheric Cryochemistry: Oxygen Atom Reaction with the Fluorocarbon Freon 11 in Matrices. FTIR Spectra of Isolated COFCl and COFCl: $\mathrm{Cl}_{2}$ Complex in Solid Ar. J. Phys. Chem. 1992, 96, 8069-8073. 
(31) Sanhueza, E.; Heicklen, J. The Oxidation of CFClCFCl and $\mathrm{CF}_{2} \mathrm{CCl}_{2}$. Int. J. Chem. Kinet. 1975, 7, 399-415.

(32) Etminan, M.; Highwood, E. J.; Laube, J. C.; McPheat, R.; Marston, G.; Shine, K. P.; Smith, K. M. Infrared Absorption Spectra, Radiative Efficiencies, and Global Warming Potentials of NewlyDetected Halogenated Compounds: CFC-113a, CFC-112 and HCFC133a. Atmosphere 2014, 5, 473-483.

(33) Davis, M. E.; Bernard, F.; McGillen, M. R.; Fleming, E. L.; Burkholder, J. B. UV and Infrared Absorption Spectra, Atmospheric Lifetimes, and Ozone Depletion and Global Warming Potentials for $\mathrm{CCl}_{2} \mathrm{FCCl}_{2} \mathrm{~F}$ (CFC-112), $\mathrm{CCl}_{3} \mathrm{CClF}_{2}$ (CFC-112a), $\mathrm{CCl}_{3} \mathrm{CF}_{3}$ (CFC113a), and $\mathrm{CCl}_{2} \mathrm{FCF}_{3}$ (CFC-114a). Atmos. Chem. Phys. 2016, 16, $8043-8052$.

(34) Durig, J. R.; Davis, J. F.; Guirgis, G. A. Conformational Stability, Barriers to Internal Rotation, Ab Initio Calculations and Vibrational Assignment for Chlorodifluoroacetyl Chloride. J. Mol. Struct. 1994, $328,19-35$.

(35) Stuckey, W.; Heicklen, J.; Knight, V. Formation of 2,3Epoxyperfluoropropionylfluoride from the Mercury Photosensitized Oxidation of 1,3-Perfluorobutadiene. Can. J. Chem. 1969, 47, 23292330.

(36) Hodnebrog, Ø.; Etminan, M.; Fuglestvedt, J. S.; Marston, G.; Myhre, G.; Nielsen, C. J.; Shine, K. P.; Wallington, T. J. Global Warming Potentials and Radiative Efficiencies of Halocarbons and Related Compounds: A Comprehensive Review. Rev. Geophys. 2013, $51,300-378$. 